\title{
The Consequences of the Economic Devastations of COVID-19 in Mexican Education 2020
}

\author{
Saúl Robles-Soto ${ }^{1 *}$, Elena Zhizhko ${ }^{2}$ \\ ${ }^{1}$ EDD, Professor of the Academic Unit of Economics, Autonomous University of Zacatecas, Mexico \\ ${ }^{2} \mathrm{PhD}$ and Dr. hab. Professor of the Doctor Program in Humanities, Academic Unit of Humanistic Studies, Autonomous University of Zacatecas, \\ Mexico
}

DOI: $10.36348 /$ sjef.2021.v05i01.001

| Received: 22.12.2020 | Accepted: 02.01.2021 | Published: 09.01.2021

*Corresponding author: Saúl Robles-Soto

\section{Abstract}

This article presents the results of a scientific economic research, which goal was to reveal the economic indicators resulting from two crises never seen before in Mexico: on the one hand, the health crisis caused by COVID19 and on the other hand, the economic crisis that has been dragging on for several decades. The authors analyzed from the modern conventional economy using the inferential deductive method, the statistical information of the five months of the year 2020 (April-August) regarding the gross domestic product, employment and unemployment in Mexico in order to understand the two crises and propose the alternatives of its solution. The study showed that the average growth rate in employment during the last 36 years in Mexico (neoliberal model) was 1.8\%, while unemployment increased in the same period at a rate of $3.4 \%$, an indicator that shows the incapacity of the model to satisfy the demand for labor of the population. Likewise, in the unemployment variable, the neoliberal model implemented since the eighties of the twentieth century in Mexico, has resulted in a low dynamism in GDP, unlike that achieved in the nationalist period, with the consequent reduced number of jobs each six-year term and with it, a considerable increase in the number of unemployed. Keywords: Modern conventional economy; Mexican economy; economic consequences of COVID19; gross domestic product; employment and unemployment.

Copyright (C) 2021 The Author(s): This is an open-access article distributed under the terms of the Creative Commons Attribution 4.0 International License (CC BY-NC 4.0) which permits unrestricted use, distribution, and reproduction in any medium for non-commercial use provided the original author and source are credited.

\section{INTRODUCTION}

The global health problem caused by the socalled COVID19 in the world has brought consequences never seen before, so it's necessary to adapt to the events that are looming very negative in terms of health in line with the economic ones. Until the beginning of August 2020, there is talk that the loss of human life has exceeded 750 thousand in the world due to COVID19 and will continue to increase until the most effective remedy for this, the corresponding vaccine, isn't achieved. Likewise, those infected exceed 21 million people worldwide, with no signs of improvement in the coming months.

It should be taken into account that the number of recovered also increases, which allows a respite from such a painful and dangerous disease. This happens because of having resisted the disease and being able to give plasmas to the infected to regain health. There is no doubt that the health problem caused by COVID19 was not contemplated to attack it promptly, so emerging strategies have been carried out in this regard that as far as possible have been successful to counteract the pandemic in Mexico and in the world. One of these measures refers to moving to remote activities in the regular education system.

It should be noted that these measures have not been entirely homogeneous in the countries, especially in those that have suffered the greatest damage, both in deaths and infections. Thus, for example, in the USA, measures were taken in each state of the country, but without the most satisfactory results possible, which translates into being the country with the highest number of deaths and infections until the month of August 2020. In that month, the number of deaths in the USA exceeded 163,533, and with regard to number of infections, the figure was 5 million 98 thousand 452, with prospects of continuing to increase in the following months.

In contrast to the above, China has implemented a series of measures aimed at counteracting deaths and infections, with total closures in large cities (such as in the region where the disease originated), and reduced deaths and illness in its inhabitants. In the case of Mexico, it does everything

Citation: Saúl Robles-Soto \& Elena Zhizhko (2021). The Consequences of the Economic Devastations of Covid-19 in Mexican Education 2020. Saudi J Econ Fin, 5(1), 1-15. 
possible to counteract the pandemic and it's expected that deaths will not exceed 55,000 and the number of the infected will not exceed 500,000. However, the measures have not been fully accepted by certain states in the country that continue to insist on the total opening of all economic activities so as not to lose more in monetary terms with the almost total stoppage of production.

It's worth mentioning that the problem of the economic consequences of COVID19 has been periodically studied by economists at the international and national level from different perspectives, with the modern conventional economy and political economy standing out, each with its respective defenders: Alcalá [1], Bendesky [2], Cruz-Martínez [3], Gómez [4], Jiménez [5], Krugman [6, 7], Muñoz and Urrutia [8], Robles [9], Tanuro [10], among others.

From the economic point of view, the pandemic will cause a change in the way of facing the country's socio-economic problems. The so-called new normal will be subject to a paradigm shift, from the proliferation of the new remote market to production with new methods in companies, in order to adapt to the guidelines dictated by specialists in economic terms. Although the fundamental thing must be the preservation of human lives, they are subject to economic fluctuations, which are the sustenance for survival, a hypothesis proven through history that we must take into account.

The objective of this work is to clarify the economic aspects of Mexico in the COVID19 pandemic period and its consequences, highlighting variables such as gross domestic product (GDP), gross domestic product per capita, employment and unemployment. The above, through economic analysis using the inferential deductive method to draw our own conclusions based fundamentally on timely information analyzed and managed in the period Abril-August 2020. This information was processed and reflected in an econometric model which made it possible to show in a timely manner the results obtained so far that reflect the behavior of the Mexican economy in its four fundamental variables that are presented in this work with their respective graphs and tables prepared and contrasted in the last five months (April-August 2020 ).

\section{THE MAIN RESEARCH MATERIAL}

Every economic system is based on the management and understanding of the Gross Domestic Product (GDP), which, by the way, has been questioned by the current Mexican President Andrés Manuel López Obrador (AMLO) $\left[{ }^{1}\right]$, as a variable to measure the

\footnotetext{
${ }^{1}$ AMLO has highlighted that since the 1940s, the economists have considered GDP as the fundamental variable to measure the behavior of the economy in Mexico, without considering people's well-being. He
}

growth and development of a country. AMLO always argues that the makers of economic policy in Mexico have been concerned with GDP to measure the country's growth, however, they have not been interested in the levels of well-being and much less in the reduction of poverty, which continues to be a very important aspect without possibilities of being solved until the moment. Likewise, AMLO calls economists with this bias as technocrats and supporters of the dictates of international organizations specialized in managing GDP in the world, such as the World Bank, the International Monetary Fund, the Inter-American Development Bank and the main financial rating agencies.

On the other hand, for the Nobel Prize in Economics Joseph Stiglitz, the new coronavirus pandemic showed that the world economy works without a safety net. He advocated, in an interview, to replace gross domestic product with a better indicator of economic health of a country [8]. Today's political discourse is imbued with the idea of a green recovery. What should be the basis for this shift towards a more sustainable economy? Maybe, we should think, what kind of economy do we want after this pandemic and we shouldn't go back to where we were. We knew then, and we know even more today that there are many inequalities. What we have to do is steer the economy in a direction that reflects all of these concerns. GDP is not a good measure. It doesn't take into account inequalities. The most important indicator is the impact of greenhouse gas emissions. Not just carbon dioxide, but also methane. Each has different dimensions, such as its useful life and its power. On June 12, 2020 in one of the most prestigious newspapers in Mexico $L a$ Jornada, Muñoz and Urrutia stated that:

GDP continues to be the key indicator to evaluate the success of any policy. Is influenced the shift to a new growth model by the tools we use to measure it? We believe that indicators are important in two respects. In our new report (for the Organization for Economic Cooperation and Development), we underline that if we had had better measures, we would have had a better idea of the damage that the 2008 crisis was causing. More generally, we should work on a better measure of the health of the economy to see to what extent our stimulus policies are actually improving our societies. Our focus on GDP has not made us realize that the society we have created is not resilient. It hasn't allowed us to calculate the strength of our economy. To put it another way, there is a big difference between whether a vehicle has a spare tire or not. However, in the way we measure GDP, a vehicle without a spare wheel is more efficient than a vehicle

think, that it's necessary to readjust the measured to another type of quantification, where peoples happiness, a topic that will be analyzed in future dates, stands out. 
with a spare wheel, because it costs less. We have created an economy with no spare tire, no extra hospital beds. We have not prepared for the pandemic; we have not done many things that would have allowed us to respond to the pandemic better. Not that we could have prevented it, but we could have had a much more resilient, much more responsive economy, and we don't think, that our stats tell us that [8].

There is no doubt that the issue is for reflection in these dramatic moments in the world that we are experiencing because of the pandemic and that greatly affects the economic sphere. Returning to the case of GDP, the forecasts for Mexico in 2020 are indicated by the following data from private financial institutions: all of them forecast a negative fall in GDP that ranges from the highest by Credit Suisse with -9.6 , to less by Berclays with -6.5 . It's noted that -7.93 would be the average of the 11 institutions that forecast the behavior of GDP in Mexico for the first semester of 2020, a figure for some too optimistic because they consider that the fall will be even greater. Otherwise, the defenders of the $\left.\mathrm{T} 4{ }^{2}\right]$ represent that they have always stated that the decline in the economy in the country will be negative, but not in the terms of the financial institutions indicated in graph number 1. For AMLO, the recovery should begin to be noticed at as of July 2020 .

Given that, the health crisis becomes stale for not finding the corresponding vaccine until the third week of June 2020, optimists in this claim that by early 2021 the vaccine will appear to counter the pandemic in the world. Furthermore, it's repeatedly argued that COVID19 is a disease that was born to stay. Thus, until June of this year, the danger of outbreaks in countries that had already overcome the health crisis is again noticeable, so governments make desperate attempts to counteract its effects. As more complete and recent data appear, this information will surely be incorporated to update the forecasts. However, what is a constant so far is the perception that the Mexican economy will be one of the ones that will regress the most due to the pandemic.

\footnotetext{
${ }^{2}$ T4 refers to the radical "fourth transformation" of Mexico announced by the current leftist president Andrés Manuel López Obrador (2018-2024). The first three transformations took place in 1855-1866 with President Benito Juárez and the time of the Reformation; 1910-1913 with President Francisco I. Madero with the beginning of the Mexican Revolution; 1934-1940 with the socialist-oriented president Lázaro Cárdenas.
}

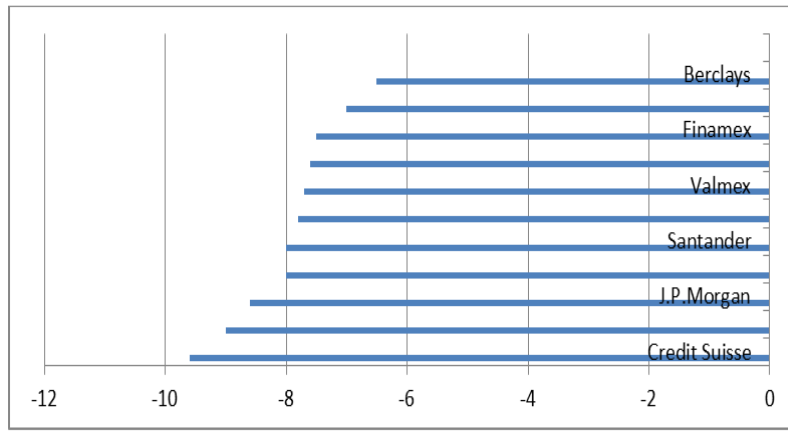

Graph-1: GDP forecast of 12 financial institutions for Mexico 2020, in percentage terms

Source: Own elaboration with data from the Applied Economics Laboratory of the Autonomous University of Zacatecas, June, 2020.

Returning to the analysis of GDP for Mexico, it's worth doing a little history about this indicator used throughout the world to measure the behavior of the economy in countries. GDP was created at the request of Simon Kuznets (USA), as an economic indicator after the crisis that occurred in the period 1929-1933. Although he claimed later that, this measurement of economic growth was not enough to assess the wellbeing of a society [4]. From the foregoing, AMLO's appreciation emerges to analyze thoroughly the GDP in Mexico by a specialist in the economic branch after the problem of the pandemic passes in the country. Since 1943, GDP has been used annually, standardizing itself throughout the world to make international comparisons. Its main objective is to quantify the value of the production of goods and services and their respective changes from year to year in order to know the behavior of the Mexican economy, its sectors and branches in order to determine growth, stagnation or decline and carry out the necessary changes and economic policies.

Therefore, GDP still is considered as a basic statistic for understanding the functioning of the economy and making decisions about it. Hence, it's a quantitative measure, but only that. Therefore, it doesn't indicate the development, the distribution of income and the wealth of the country, it doesn't provide for the social advance or retreat of well-being. This has guided President AMLO to review GDP and take into account social development, which measures growth and happiness, an issue in those quantitative indicators aren't interested.

It's therefore necessary to adequately measure well-being in Mexico, requiring accurate, complete and timely statistics that account for the distribution of income, concentration of wealth, formal employment, occupation with its respective characteristics, access to services such as health, water, drainage, telephony, to the tax contribution of companies, their personal income, environmental quality, etc. Since May 22, 2020 , in the midst of the health and economic crisis, AMLO has suggested an alternative indicator to GDP 
that allows determining economic growth, well-being, and degrees of inequality and happiness of the people [8]. To make changes in the measurement of GDP, the president will convene econometricians, mathematicians, economists, sociologists, anthropologists, psychologists, and other specialists. The main idea of the proposal is to better distribute income, increase welfare, it will be useless to have economic growth if it isn't associated with equality; there shouldn't grow to grow, there should be honesty with well-being, culture and happiness, is what AMLO proposes.

The following information presented in table number 1 for the year 2019, reflects the world GDP in several advanced and underdeveloped countries, yielding the results in quantitative terms, showing the average percentage in the 2014-2019 period, as well as projected data for the year 2020 . The step taken by two Asian economies like India and China, which had the highest GDP growth rates in percentage terms, with an average of $6.65 \%$ for the first and $3.06 \%$ for the second, is immediately noticeable. These data showed the sustained growth of the two countries, which far exceeded the rest, both developed and underdeveloped, in 2018 and the 2014-2019 average as indicated in table 2. At the same time, it's highlighted that the USA and Canada had an average growth in their GDP in percentage terms of $2.43 \%$ and $1.90 \%$ respectively. Regarding Mexico and Chile, Latin American countries, the second had the highest growth in percentage terms with $2.81 \%$, while the growth of the first was only $2.32 \%$.

It's necessary to highpoint that the low growth of GDP in Mexico is due to the change of regime, which must overcome a series of economic inconveniences. This inopportuneness are reflected in the abandonment of private investments in the productive sphere, especially due to the paralysis of the prianist $\left[{ }^{3}\right]$ project. This project related to the new international airport of Mexico City, was intended to be carried out in Texcoco. When it was suspended, this situation affected many interests of businesspersons who had acquired large tracts of land adjacent to the suspended project in order to develop luxurious urban subdivisions around the new airport.

Reviewing the data in Table-1, we can noted that for the year 2018, the variation for the world was $3.61 \%$ and for the advanced economies, it represented $2.27 \%$ for the same year 2018. Regarding the lagging economies, the GDP figure in percentage terms for the year 2018 was $4.52 \%$, and the most representative is located in the Asian developing countries with a surprising $6.4 \%$. The highest amount in terms of variation in the world, which makes it possible to stand out from now on the importance of these countries in terms of economic growth represented by GDP.

Table-1: World GDP, percentage change, year 2018, period 2014-2029 and projection for the year 2020 .

\begin{tabular}{|l|l|l|l|}
\hline World GDP & $\begin{array}{l}\text { Year } \\
\mathbf{2 0 1 8} \\
\mathbf{3 . 6 1}\end{array}$ & $\begin{array}{l}\text { Average } \\
\mathbf{2 0 1 4 - 2 0 1 9}\end{array}$ & $\begin{array}{l}\text { Projection for } \\
\text { the year 2020 } \\
\mathbf{2 . 3}\end{array}$ \\
\hline Advanced & 2.27 & 3.30 & 2.7 \\
Economies & & & \\
\hline USA & 2.93 & 2.45 & 1.1 \\
\hline Canada & 1.88 & 1.90 & 1.3 \\
\hline Germany & 1.52 & 1.8 & 1.2 \\
\hline Latin America & 1.05 & 1.8 & 0.8 \\
\hline Chile & 4.02 & 2.81 & 1.1 \\
\hline Mexico & 2.0 & 2.32 & -4.3 \\
\hline Brazil & 1.11 & -0.84 & 1.6 \\
\hline Argentina & -2.48 & -0.34 & -4.2 \\
\hline Asia & 6.4 & 6.66 & 4.3 \\
\hline China & 6.57 & 6.65 & 4.1 \\
\hline India & 3.06 & 2.8 & 3.2 \\
\hline
\end{tabular}

Source: Own elaboration with data from the Applied Economics Laboratory of the Autonomous University of Zacatecas, World Bank, International Monetary Fund, Inter-American Development Bank, various years, 2020.

Regarding the GDP quantified in trillions of dollars, table number 2 presents the data for the years 2018 and 2019, making the differentiation in terms of advanced and underdeveloped countries. Six countries, among which is Mexico, are presented with the lowest amount with respect to the countries indicated. Two economic systems stand out that far surpass the others, such as the USA and China. These countries surpass the set of Latin American countries and part of Africa, which together don't exceed 6.892 trillion dollars, when the USA has 21.332 trillion, and China counts for the year 2019 with 15.24 trillion dollars. Hence, the constant struggle in 2019 and 2020 to see who controls the world in monetary terms based on GDP.

Gearing Mexico, in 2018, it had an amount of 1.22 billion dollars and for the year 2019, it increased to an amount of 1.345 billion dollars. It should be considered that in table number 1 the case of Chile was taken as the one that had grown the best in terms of percentage terms in Latin America, but when compared in terms of dollars, it doesn't appear in the ranking of the best placed. It will be because its little participation in this area, so it doesn't appear in table number 2.

\footnotetext{
${ }^{3}$ Authors' note: the prianist project is a combination of two political parties: the Institutional Revolutionary Party and the National Action Party, which are colloquially called prianism, which dominated the Mexican political scene for 83 years.
} 
Table-2: GDP of developed and underdeveloped economies in trillions of dollars for the year 2019

\begin{tabular}{|l|l|l|}
\hline Countries & $\mathbf{2 0 1 8}$ & $\mathbf{2 0 1 9}$ \\
\hline WORLDWIDE & 84.93 & 89.56 \\
\hline Developed economies & 52.243 & 52.03 \\
\hline USA & 20.58 & 21.332 \\
\hline China & 13.368 & 15.24 \\
\hline Germany & 3.951 & 4.02 \\
\hline Underdeveloped economies & 33.687 & 34.906 \\
\hline India & 2.719 & 2.983 \\
\hline Brazil & 1.868 & 1.942 \\
\hline Mexico & 1.222 & 1.345 \\
\hline Latin America & 5.25 & 5.32 \\
\hline Sub-Saharan Africa & 1.642 & 1.73 \\
\hline Sourc: Own
\end{tabular}

Source: Own elaboration with data from the Applied

Economics Laboratory of the Autonomous University of

Zacatecas, World Bank, International Monetary Fund, Inter-

American Development Bank, various years, 2020.

Table number 3 refers to the total GDP by sectors for Mexico corresponding to the first quarter of
2020 in thousands of pesos, as well as the percentage and variation obtained with respect to the previous year 2019. With the exception of sector I, referring to agriculture, forestry and fishing, the other sectors, industrial and services, have had negative variations, which immediately reflects a situation to be faced by the government of President AMLO.

We must bear in mind that investments in these two sectors, II and III, the bulk of them in terms of productive investments, are made by private initiative, which since the beginning of 2019 has been at odds with the so-called Fourth Transformation (T4), having a very well defined orientation called "the poor first". Likewise, the most significant investments in T4 will be works in three directions: increasing the potential in hydrocarbon generation with the new refinery in Dos Bocas Tabasco, the reactivation of the rail service with the construction of the Mayan Train and the new airport Felipe Ángeles in St. Lucia, Mexico.

Table-3: Total GDP by sectors corresponding to the first quarter of 2020 in thousands of pesos

\begin{tabular}{|l|l|l|l|}
\hline Activities/sector & Thousands of current pesos & \% & Variation \% 2020/2019 \\
\hline GDP & $24^{\prime} 333,531$ & & -1.4 \\
\hline Net taxes on production & $1^{\prime} 840,304$ & & -3.5 \\
\hline GDP at basic prices & $22^{\prime} 4923,227$ & 100 & -1.3 \\
\hline Sector I & 838,349 & 3.7 & 1.4 \\
\hline Sector II & $7 ' 113,817$ & 31.6 & -2.9 \\
\hline Sector III & $14^{\prime} 541,062$ & 64.6 & -0.7 \\
\hline
\end{tabular}

Source: Own elaboration with data from the Applied Economics Laboratory of the Autonomous University of Zacatecas, World Bank, International Monetary Fund, Inter-American Development Bank, various years, 2020.

It can be deduced from table number 3 that tertiary activities continue to predominate in the conformation of the national GDP with an amount of $144^{\prime} 541.062$ billion pesos, corresponding to $64.6 \%$ of the national total. In second place, is the industrial sector with $7^{\prime} 113,817$ thousand million pesos with $31.6 \%$. In last place is the first sector of the economy, such as agriculture, with only 838,349 million pesos, representing barely $3.7 \%$.

The above data show the increasingly noticeable neglect of the first sector of the economy in Mexico. This situation, far from benefiting the country as a whole, makes it increasingly dependent on abroad, a problem that the current government of the republic intends to modify in order to give it the required importance in the next four years. It should be noted that the GDP data for 2020, have had a negative impact on most activities by sectors if compared to 2019, unleashing agriculture, livestock and forestry with positive increases, not so all the rest of the agricultural sector.

When locating ourselves in the industrial sector, mining, oil and gas extraction stand out, as well as food with a positive trend compared to 2019. However, all other items have negative results.
Regarding the third sector, it stand out with positive results in the media and telecommunications, corporate and business management, as well as real estate, rental and intangible services, all the others have negative data.

It's necessary to take into account that the growth that the first sector has had, is a consequence of the continuous support that has been granted by various programs implemented by the AMLO's government. President manifests repeatedly that agriculture, livestock and fishing must re-emerge in the present administration, leaving aside the massive importation of basic grains for the population, as did the previous administration. Below is graph number 1 that corresponds to the total GDP in percentage terms for the first quarter of each year from 2016 to 2020.

The alarming drop for 2020 is immediately highlighted. In its first quarter, the result is negative by $1.4 \%$, which immediately shows an economic problem of fundamental importance that the current federal administration must solve to avoid as much as possible the effect of the health crisis that greatly affects the economic sphere. However, it must be clarified that this situation isn't unique to Mexico, it's a general problem that affects the entire world economy, a sui generis 
situation that we had never suffered when we were going through two crises, health and economic.

Graph 2 indicates that the highest growth in the last 5 years took place in 2017 with $3.4 \%$, an increase with respect to the previous year of $0.7 \%$. However, as of the following year 2018, the trend was downward to stand at $1.5 \%$, that is, a decrease of $1.9 \%$, for the following year 2019, with the appearance of the new government headed by AMLO, growth was $1.1 \%$, with a decrease compared to the previous year of $0.4 \%$. It's necessary to consider that the data for the year 2020 is only contemplated until the month of May, so we don't doubt that as the months progress, the negative data on total GDP will increase.

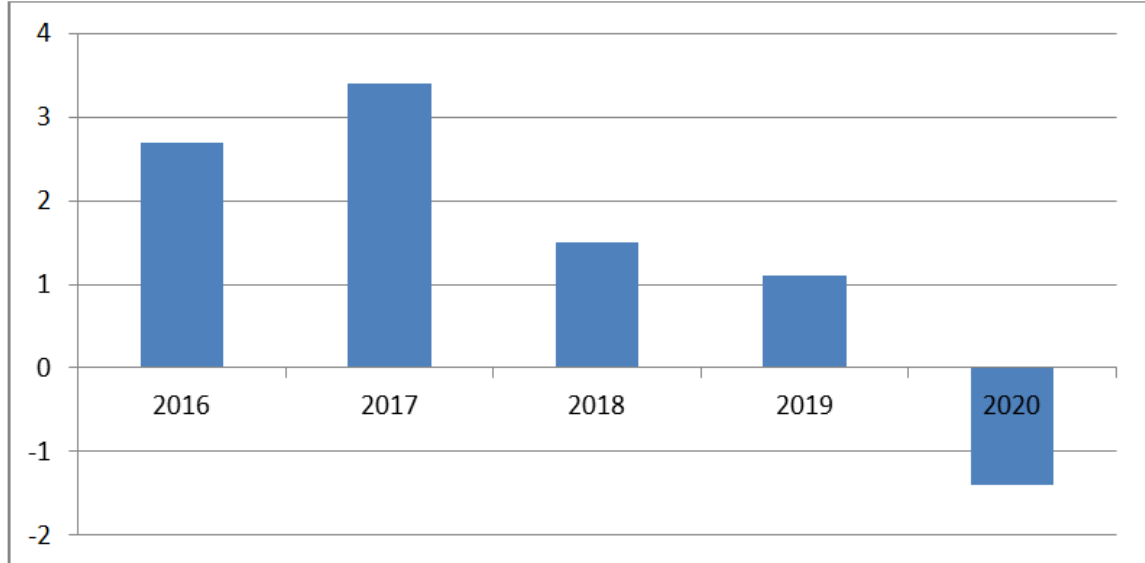

Graph-2: Total GDP in percentage terms for the first quarter of each year from 2016 to 2020

Source: Own elaboration with data from the Applied Economics Laboratory of the Autonomous University of Zacatecas and the National Institute of Geography and Informatics (INEGI), June 2020 [11].

The change of administration that took place in December 2018, has caused significant decreases in GDP (for the first quarter of 2019 and 2020), highlighting among other factors the flight of Mexican capital abroad. Nevertheless, offsetting with the arrival of greater resources via foreign direct investment and the sending of workers' remittances across borders, particularly those from the USA and Canada. Graph number 3 indicates the GDP activities for Mexico during the first quarter of the years 2016 to 2019 in percentage terms by sectors, indicating what we had emphasized in previous lines, where the decrease in industrial and services GDP for the year 2019 stands out, representing the -2.9 for the industrial sector and 0.7 for the services sector.

It should be noted that this decrease in the two sectors mentioned, will be more noticeable in the remainder of 2020 due to the pandemic that the country is suffering and will continue until the end of the year, with the repercussions for the economy as observed since March when productive activities were paralyzed throughout the country with the corresponding consequences affecting the entire population.

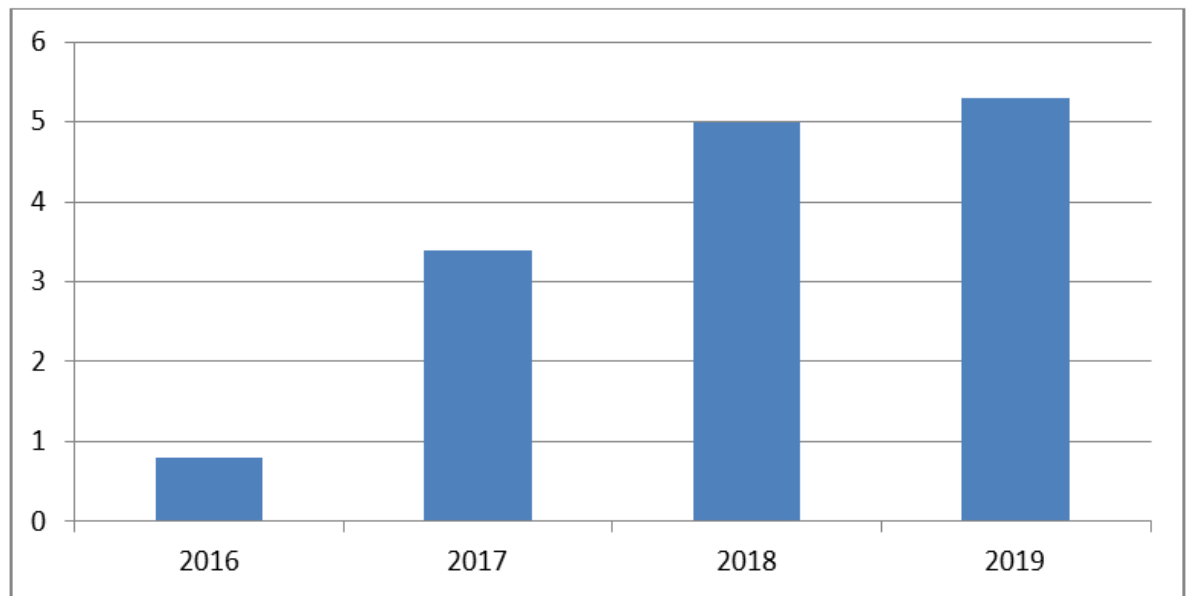

Graph-3: Agricultural GDP as a percentage, 2016-2019 period

Source: Own elaboration with data from the Applied Economics Laboratory of the Autonomous University of Zacatecas and the National Institute of Geography and Informatics (INEGI), June 2020. 
Graph number 3 indicates the GDP by agricultural activity during the first quarter of each year for the 2016-2019 period in percentage terms. As noted above, the primary sector is the only one that didn't have negative results. It's expected that this first sector of the economy in Mexico will recover its place as a large-scale exporter that allows it to move towards better and larger markets, leaving aside the position of previous six-year terms that preferred to import agricultural goods because they were considered cheaper than producing them internally, a position that has changed in the current six-year term.

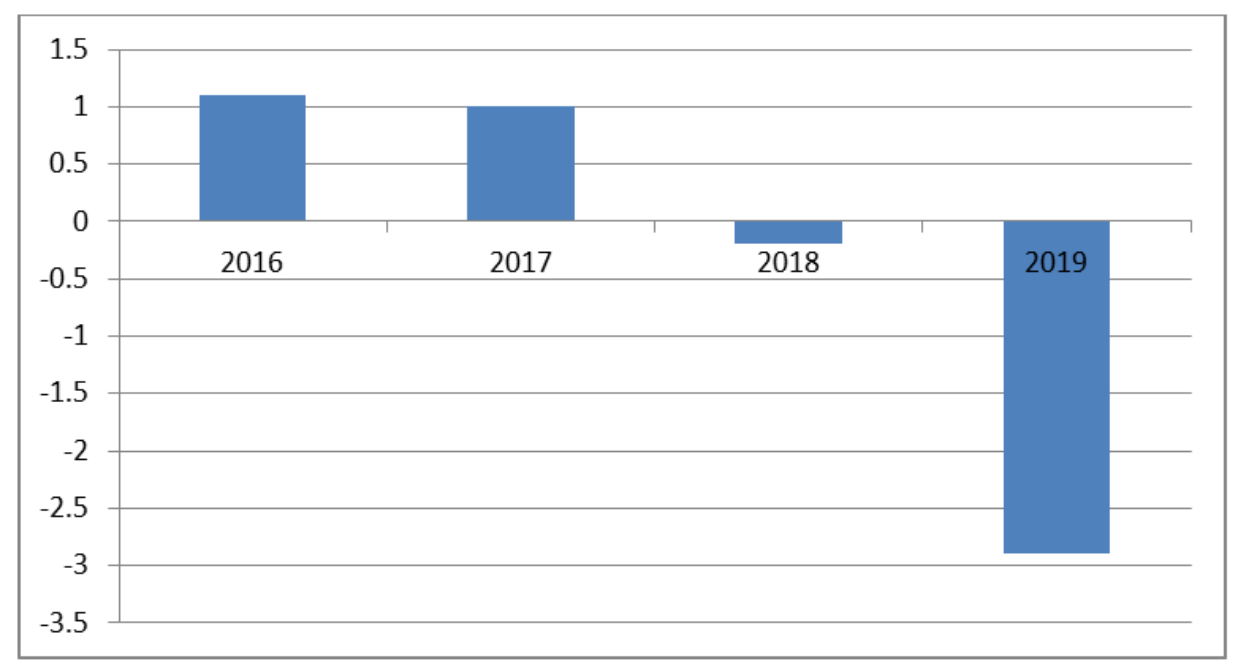

Graph-4: Industrial GDP in percentage, 2016-2019 period

Source: Own elaboration with data from the Applied Economics Laboratory of the Autonomous University of Zacatecas and the National Institute of Geography and Informatics, June 2020.

For the industrial sector, it had a negative behavior from the year 2018 and is emphasized in the year 2019 until reaching $-2.9 \%$. Situation that will be accentuated in 2020 because of the health pandemic that has a direct impact on the economic sphere. It's necessary to insist that for the year 2019, there were continuous friction between the private initiative and the government sector, to the extent of directly confronting each other. The most significant cases have been the back and forth between the Mexican business chambers with the T4, with the most outstanding being the Mexican Employers' Confederation (COPARMEX), the Business Coordinating Council (CCE), the National Chamber of the Transformation Industry (CANACINTRA) and the National Confederation of Commerce Chambers (CONCANACO).
However, President AMLO has also been concerned about ironing out rough spots with the business sector, arguing that it will always be preferable to have a good agreement than a constant fight. Thus, by 2020 , more than 32 billion pesos ${ }^{4}$ had been paid in taxes that were previously frozen or not paid by political agreements with the prianist administration.

\footnotetext{
${ }^{4}$ These are the cases of the companies WalMart, Soriana, Oxxo and Peñoles, which have been the most significant. For 24 years (1996-2020), they didn't pay taxes to the Mexican state, having as a practice the protection (amparos) that processed accounting offices to evade taxes. Fortunately, with the current federal government, the collection of taxes by four companies has been solved, leaving the remaining 11 large companies that are installed in Mexico to pay in the near future.
} 


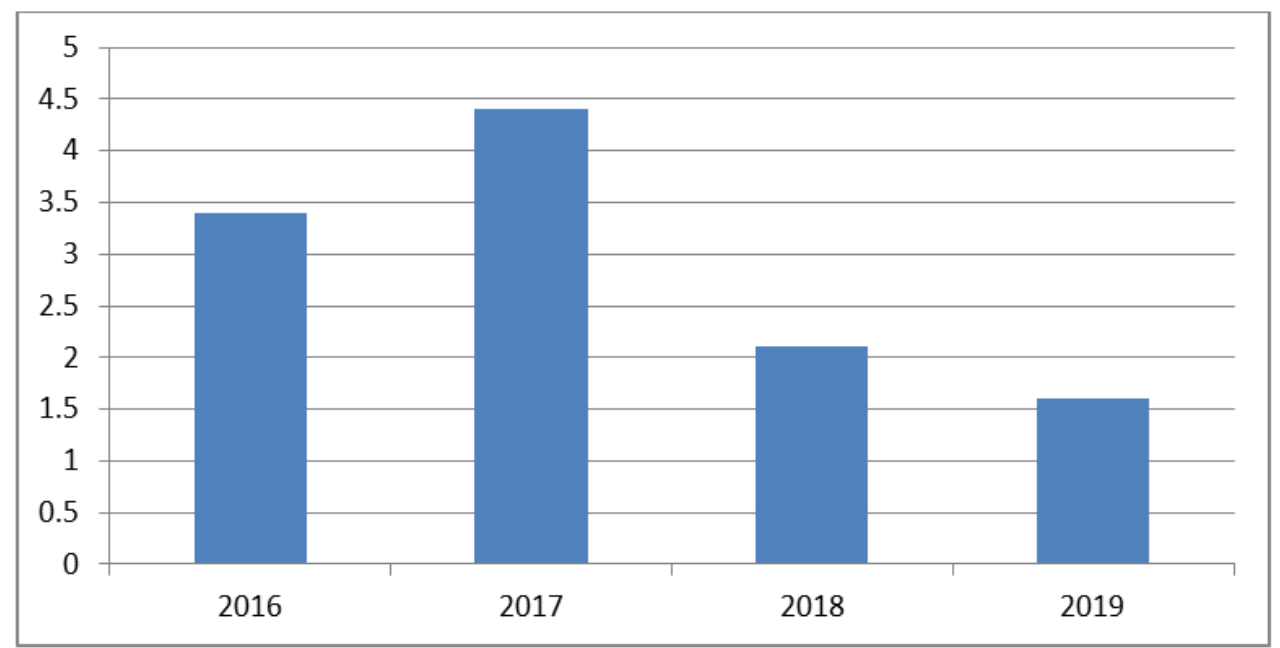

Graph-5: GDP services sector in percentage, period 2016-2019

Source: Own elaboration with data from the Applied Economics Laboratory of the Autonomous University of Zacatecas and the National Institute of Geography and Informatics, June 2020.

There is no doubt, that the behavior of the Mexican economy during the years 2018 and 2019, has been downward, as a result of the arguments cited above and that can be summarized in a change of economic paradigm that refuses to fall. Now, it's thought to transit towards new paths, in which preference will be given to the most needy in Mexico, leaving aside the great privileges, to which the potentates of always were accustomed. Hence, the continuous decrease in percentage terms of the two sectors of the economy indicated both the industrial sector and the service sector, as reflected in graphs 4 and 5 .

The trends for the next months of the year 2020 with reference to GDP, in 13 countries of the world are represented in table number 4 . With the exception of China and India that forecast positive trends of $1.2 \%$ and $1.9 \%$ respectively, all the others will have negativity in their figures, something that must be taken into account by specialists in the field. There is no doubt, that growth trends based on the behavior of GDP worldwide, will bring repercussions never before known as a result of the conjunction of the health and economic crises that didn't allow time to prepare for it, so we must get used to the immediate future to live situations difficult to solve in the short and medium term.

In the case of Mexico, the projection made by the IMF, which places it at $-6.6 \%$ in 2020 , is a figure that should be reviewed. The indicators from other sources such as Mexican Bank (Banco de México) itself oscillate between $7 \%$ and $9 \%$. Likewise, private financial institutions state repeatedly that the economic decrease will be in the order of $12 \%$. Finally, academics and economic specialists point out that the drop in GDP in the country can even be above $15 \%$. Table number 5 is presented below, referring to the projection of GDP in 13 countries for the year 2020 in percentage terms.
Table-4: GDP projection in 2020 for 17 countries in percentage terms.

\begin{tabular}{|l|l|}
\hline Countries & Increase in \% \\
\hline India & 1.9 \\
\hline China & 1.2 \\
\hline Sweden & -0.3 \\
\hline Japan & -5.2 \\
\hline Brazil & -5.3 \\
\hline Russia & -5.5 \\
\hline USA & -5.9 \\
\hline Canada & -6.2 \\
\hline UK & -6.5 \\
\hline México & -6.6 \\
\hline Germany & -7.0 \\
\hline Spain & -8.0 \\
\hline Italy & -9.1 \\
\hline
\end{tabular}

Source: Own elaboration with data from the Applied Economics Laboratory of the Autonomous University of Zacatecas and the National Institute of Geography and Informatics, June 2020.

In itself, all international organizations, investment banks and even the federal government assume that the Mexican GDP will be negative this year 2020 , but the dissent is focused on how low the negativity will be. For example, Credit Suisse estimates a drop of 9.6 percent and the Ministry of Finance and Public Credit of Mexico places it at 3.9. Continuing with the Mexican case regarding the behavior of GDP, at the end of May 2020, the National Institute of Statistics, Geography and Informatics (INEGI) published the revised results of economic activity for the first quarter of 2020 and with it the nominal value of GDP. In pesos, the indicator totaled 24.33 billion pesos.

However, in real terms -discounting the depreciation of the currency due to inflation- production in the country totaled 18.20 trillion pesos, its lowest 
level since what occurred between April and June 2017 [12]. Next, we present what refers to the GDP per capita in Mexico, a variable that reflects the behavior of the same total GDP generated in the country and that as it decreases, brings about a fall in the following item.

GDP per capita is the quotient of the division between total GDP and the number of inhabitants. Another way to visualize the GDP per capita would be the relationship in the total value of the set of final goods and services generated by the economy in a defined period and the number of inhabitants. GDP per capita will decrease by $3.0 \%$ in the world by 2020 . In advanced economies, $-6.1 \%$ and in underdeveloped economies, $-1.1 \%$ (see Table-5). For Mexico, is estimated a reduction of $-7.6 \%$. Table 6 continues to show that only four countries have negative GDP per capita such as Argentina, Chile, South Africa and Mexico, the others have increased their GDP per capita in 2019. Estimates for 2020, change radically in the table as only China and India are located as countries with a positive trend, and all the others considered, are located with negative numbers.

To illustrate the above, we present two tables referring to GDP per capita for the years 2018, 2019, 2020 and 2021. The data are estimated and projected in the table number 6 . In the table number 7 , we note also the referring to GDP per capita in current dollars for the years 2018 and 2019. In the above table, Mexico is located, compared with other countries, in the last places, which immediately reflects an economic disability that has been suffering for more than 30 years, in which there have not been favorable results for the population as a whole that translates into better and higher indices of well-being, such as GDP per capita. The data indicate that Mexico continues to be considered a lagging country with respect to countries with advanced economies.

It is a pending task for the current government led by AMLO, which doesn't fully coincide with an economic variable that really informs the behavior of well-being in the country. He always argues that constant support to the lower-income inhabitants' hasn't decreased; on the contrary, remain on the rise in order to continue reducing the social lags left by the previous governments for 32 years. With these data regarding GDP per capita in Mexico, we can conclude: it will be reduced by a fifth this year compared to the level it reached in 2019, and at the end of the government of President Andrés Manuel López Obrador, the level with which the administration began will hardly have recovered. By the end of 2018, it was 9,791 dollars, and for the following year 2019, it increased to 10 thousand. However, it is estimated that the 2020 crisis will wipe out this advance and sink the indicator to 8,028 dollars at the end of the year, although of course, private analysts and opponents of President AMLO's regime, consider that the decrease would be even greater.

The per capita GDP projection for Mexico would be located at 8 thousand 28 dollars by the end of 2020 , this in terms considered optimistic, an amount that, without a doubt, will move as the number of infected by the COVID19 decreases over the course of the next few months. Therefore, the outlook for GDP per capita in the country looks bleak, although we continue to insist, it's not exclusive to Mexico. Continuing with comparative data related to GDP per capita at market parity for the years 2019 and 2020, the previous table seats Luxembourg in first place with 115,538 dollars for the year 2019 and an estimated amount for the following year less than 113,196 . This data despite being able to decrease from one year to the next is still very high compared to the other countries indicated in table 6. In the last place (144 in the world), is cited India, a country that given its huge population and low generation of wealth transformed into GDP, results in a figure of only 2,038 dollars per capita for the year 2019 and a slightly higher projection for the following year 2020 .

Likewise, Mexico occupies the 71st place with a GDP per capita of 9,797 for the year 2019 and an increase for the following year projected in 10,118 dollars per inhabitant. The estimated projections regarding GDP per capita in the countries indicated in table 6 reflect the world, with $-3.0 \%$, as well as a negative trend for developed (with -6.1\%) and underdeveloped $(-1.1 \%)$ countries. In the same table, two countries have positive increases for the year 2020, for example, China with $0.9 \%$ and India with $0.5 \%$. All the others will have negative forecasts. Although it's necessary to establish that given the consequences of COVID19, each country will have its specificities to get out of the economic problem, so the GDP per capita will be modified at the end of 2020 and the estimate is contained in Table-5. 
Table-5: The percentage changes in GDP per capita (years 2019-2020)

\begin{tabular}{|l|l|l|}
\hline Country & Real 2019 & Estimate 2020 \\
\hline Worldwide & $\mathbf{2 . 9}$ & $\mathbf{- 3 . 0}$ \\
\hline Developed economies & $\mathbf{1 . 7}$ & $\mathbf{- 6 . 1}$ \\
\hline Canada & 0.19 & -7.5 \\
\hline USA & 1.84 & -6.4 \\
\hline Germany & 0.32 & -7.0 \\
\hline Spain & 0.75 & -8.4 \\
\hline Japan & 0.75 & -7.0 \\
\hline Underdeveloped economies & $\mathbf{3 . 7 1}$ & $\mathbf{- 1 . 1}$ \\
\hline Argentina & -3.31 & -6.7 \\
\hline Brazil & 0.34 & -5.9 \\
\hline Chile & -0.76 & -6.2 \\
\hline China & 5.75 & 0.9 \\
\hline India & 2.88 & 0.5 \\
\hline Russia & 1.39 & -5.4 \\
\hline Mexico & -1.27 & -7.2 \\
\hline
\end{tabular}

Source: Own elaboration with data from the Applied Economics Laboratory of the Autonomous University of Zacatecas and the International Monetary Fund, June 2020.

However, with respect to the other Latin American countries, Mexico continues to lead in this area, above Brazil, which is located in 77 th place in the ranking indicated in table number 6 . On the other hand, it's necessary to highlight that the USA is located in 9th place, surpassed by European countries, Asians and an Arab. According to the data in Table-6, the USA continues to be displaced by emerging countries such as Qatar and Singapore. Finally, according to the trend in GDP per capita in the world, it will suffer a considerable decrease in 2020 , as a result of the health crisis caused by COVID19, and since 2018 and 2019, the downward trend was clearly seen, which will be accentuated with greater emphasis in the years 2020 and 2021.

Especially because of the pessimistic forecasts that vaccines to effectively control the global pandemic that is suffered in most countries, will be used until the beginning of 2021, which is why the desperate attempts of governments in the world to contain the crisis (especially those most affected by COVID19), are insufficient until June 2020. In addition, the main country infected by the coronavirus is the USA, which has the highest number of deaths worldwide. It's the nation that has withdrawn considerable economic support from the World Health Organization (WHO) for the frontal combat against COVID19, something difficult to explain now that the greatest amount of support is required in the world.

Regarding the North American economy, it has suffered a series of attacks by the Chinese economic system, ranging from the impact of North American products with high tax rates towards the Asian country to prohibitions on the imports of North American articles to China. Another controversy that is aired in a very direct way between these two economic giants is the guilt regarding COVID19: the two great powers blame each other for having been the generators of the pandemic. However, the GDP of the USA as well as its GDP per capita are very far from the Asian country, with very marked differences in tables 5 and 6 . Thus, the GDP per capita in terms of dollars for the USA was 62,869 in 2019, while for China the figure barely reached only 9,580. Therefore, we can immediately see the difference between one country and another.

Table-6: GDP per capita in current dollars, years 2018 and 2019

\begin{tabular}{|l|l|l|}
\hline Ranking and country & $\mathbf{2 0 1 8}$ & $\mathbf{2 0 1 9}$ \\
\hline 1.- Luxemburg & 115,536 & 116,720 \\
\hline 2.- Sweden & 83,162 & 83,717 \\
\hline 3.- Norway & 81,550 & 81,620 \\
\hline 7.- Qatar & 70,378 & 70,820 \\
\hline 8.- Singapore & 64,579 & 64,810 \\
\hline 9.- USA & 62,869 & 65,112 \\
\hline 11.- Australia & 56,420 & 56,930 \\
\hline 65.- Russia & 11,289 & 11,320 \\
\hline 71.- Mexico & 9,797 & 10,118 \\
\hline 72.- China & 9,580 & 10,099 \\
\hline 77.- Brazil & 8,959 & 8,797 \\
\hline 144.- India & 2,038 & 2,172 \\
\hline
\end{tabular}

Source: Own elaboration with data from the Applied Economics Laboratory of the Autonomous University of Zacatecas and the International Monetary Fund, June 2020. 
Graph number six is very distinctive when combining the two previously argued variables such as total GDP and GDP per capita on average in two very representative economic models in Mexico: the nationalist model (1963-1981) and the neoliberal model (1982-2019). The disproportion between the two models implemented is immediately noticeable.

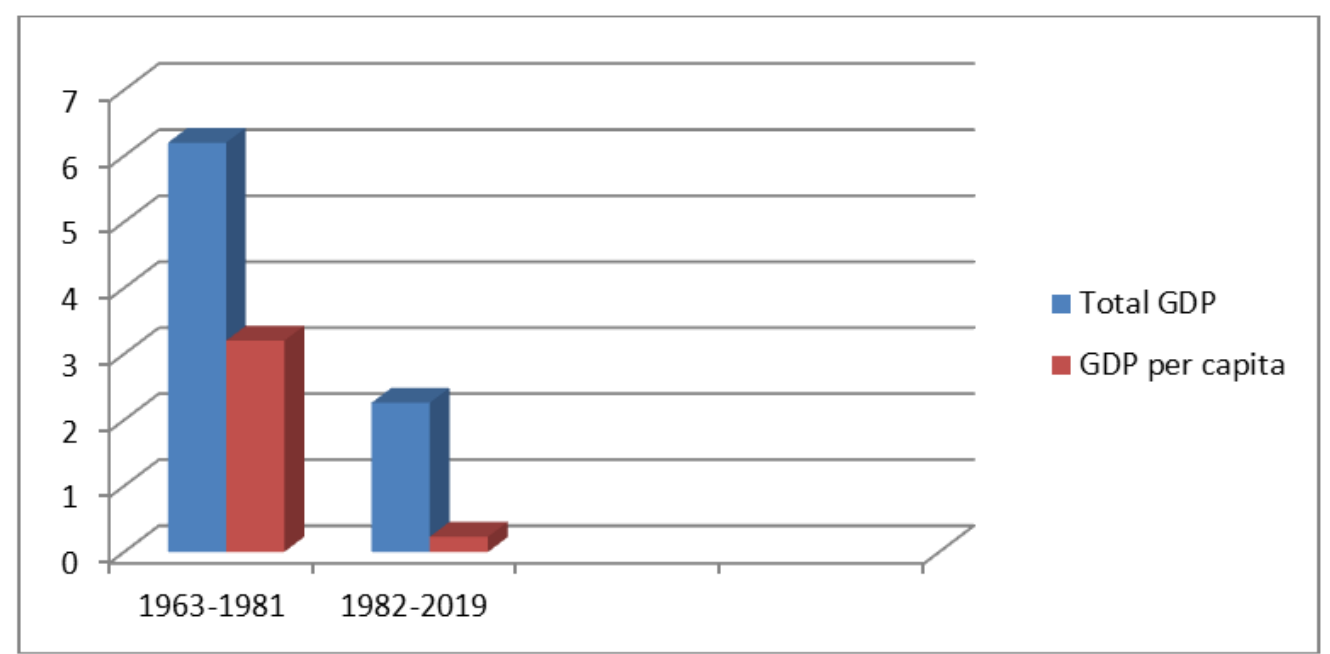

Graph-6: Total GDP and GDP per capita of Mexico, on average: nationalist model and neoliberal model

Source: Own elaboration, with data from the Applied Economics Laboratory of the Autonomous University of Zacatecas, National Institute of Geography and Informatics, Mexican Bank, Ministry of Economy, various years, 2019.

Right away, we will analyze the variable that has been very important in the times of COVID19: the employment. Since 2019, employment in Mexico has had significant vicissitudes according to the perspective of various characters, organizations and academics. There is no general agreement on the actual measurement of this variable in the country. Confronted with the evidence of the crisis, the administrations of the three Mexican government bodies (federal, state and municipal), face the situation, first, in a declarative way. Later, when the health and economic problem progresses, they look for various means (especially the financial one) to implement actions that seek to lessen the effects of the crisis, particularly on employment [13].

According to official information, collected in May 2020, the number of jobs lost in Mexico oscillated at 555,247 only for the month of April of the indicated year, an alarming figure at the height of the pandemic that is hitting the world. Likewise, 6,689 companies had withdrawn from the Mexican Social Security Institute (IMSS) in the same month of April 2020, out of a total until 2020 of 1'062,000 formally installed in the country [14]. Graph number 7 provides information about the jobs formally created in thousands of people and the unemployment rate in Mexico with respect to the years 2017, 2018, 2019 and the first quarter of 2020.

The negative effect in terms of jobs for the Mexican economic system is immediately observed, falling in the first 6 months of 2020 to 1'070,450. Historical figure in the country. Desperate attempts are being made to stop the wave of unemployment caused by the health crisis. However, until the first half of the year, the trend continued to be very negative, with a greater loss in the number of jobs expected in the remainder of the year. Undoubtedly, it will be one of the great challenges of $\mathrm{T} 4$, which resists increasing public debt to apply it to extraordinary aid to both private companies, the main generators of employment, as well as economic subsidies to those displaced by the pandemic.

President AMLO's optimism about the possibility of stopping the collapse in the level of employment in Mexico dates back to July 2020, the date on which economic activity in the country should be reactivated in all senses. The main idea is to reverse the fall of more than a million jobs as it has had since March and that continued to rise in the months of April, May and June. 


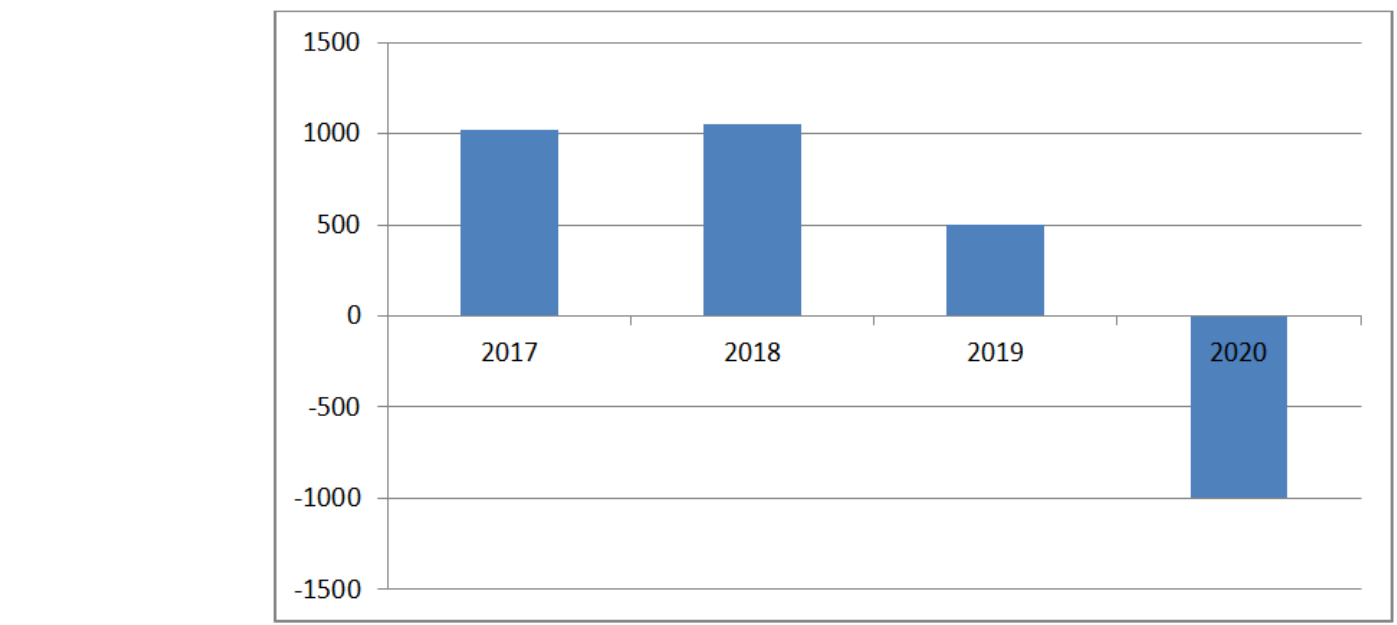

Graph-7: Creation of formal jobs in thousands for 4 years in Mexico, 2017-2020

Source: Own elaboration with data from the Mexican Institute of Social Security, National Institute of Geography and Informatics, Ministry of Labor and Social Welfare, various years, June 2020.

According to the graph number 7, the total number of affiliates in the Mexican Institute of Social Security (IMSS), was located for the month of April 2020 , in less than 20 million people, a level that can be compared with the year 2018 for the month of August. The data for the following months, May and June, were much more alarming downwards with the consequent effect for the entire Mexican population. If measured annually, the loss of jobs is 498,231 until April 2020, which became even more acute for the months of May and June, until reaching one million unemployed. The most alarming decrease in beds was registered in the hotel center of the state of Quintana Roo (with a decline of $18.1 \%$ ), the same as for Baja California Sur (a drop of $10.8 \%$ ) in the same hotel industry. However, the states of Aguascalientes, Chiapas, Colima, Michoacán, Campeche and Tabasco also reported growth in the creation of job positions in percentages from $0.4 \%$ to $2.3 \%$.

In these states, the sectors with growth were agriculture $(3.1 \%)$, social and communal services $(2.5 \%)$, communications and transportation $(2.5 \%)$ and commerce $(0.9 \%)$. Making a recapitulation since 2012 regarding the generation of formal jobs in Mexico, the following data is represented in the table number 7 . In 2012, the total number of jobs was 15.8 million and for the year 2018, this indicator reached 18.5 million, with an increase of only 2.7 million of new formal jobs in the six-year term, a figure that contradicts the whopping more than 4 million of new jobs manifested in 2018 for the month of November.

The data in the table immediately reflects the final speech that the President Enrique Peña Nieto (EPN) (2012-2018) made in 2018 when he considered the president of the employment that far exceeded the two previous six-year terms of the National Action Party (PAN) in regarding the generation of employment for Mexicans. Likewise, the optimism of the current president AMLO regarding the number of jobs created in his administration, only stands at 200 thousand, a really very low figure that must be taken into account in the current moments that he faces two serious problems, the pandemic and the economic one. This immediately means that the generation of jobs obtained in 2019 has dramatically faded in mid-June 2020 with the constant loss in the number of jobs.

Table number 7 refers to the number of jobs generated by the presidential term EPN (2012-2018) represented in thousands of people. A government period that with the exception of 2015 , in the other years had increases, starting in 2013, with 590.4 thousand, until reaching 2018 with a figure of 1'056.8 thousand jobs.

Table-7: Jobs generated in the EPN six-year term in thousands (2012-2018)

\begin{tabular}{|l|l|}
\hline Year & Jobs in thousand \\
\hline 2013 & 590.4 \\
\hline 2014 & 827.2 \\
\hline 2015 & 815.9 \\
\hline 2016 & 913.9 \\
\hline 2017 & 1007.1 \\
\hline 2018 & 1056.8 \\
\hline
\end{tabular}

Source: Own elaboration with data from the National Institute of Geography and Informatics, Applied Economics

Laboratory of the Autonomous University of Zacatecas,

Mexican Institute of Social Security and Ministry of Labor and Social Security, various years, 2018.

The total number of jobs created by President EPN stands at 5 million 211 thousand 500, a record number that was not had in the two previous six-year terms administered by the PAN in Mexico. It's necessary to contemplate that the previous figures have been highly questioned by economic specialists focused on the issue of employment in the country, highlighting, among other things, that short-time jobs (from 15 days to two months) in various subsectors were considered as 
new jobs, including construction and hotels. By the sole fact of having been registered by the employer with the IMSS, it was already projected as formal employment, although the number of days or hours worked wasn't intended.

Regarding the employment situation in recent years (period 2012-2020), for Mexico, table number 8 present, reflecting the number of jobs in millions of people, data provided by National Institute of Geography and Informatics (INEGI), Applied Economics Laboratory of the Autonomous University of Zacatecas (LEA), Mexican Institute of Social Security (IMSS) and Ministry of Labor and Prevision (STPS) by 2020 [14].

Table-8: Total jobs in Mexico 2012-2020 in millions of people

\begin{tabular}{|l|l|}
\hline Year & Total jobs in millions \\
\hline 2012 & 15.8 \\
\hline 2013 & 16.4 \\
\hline 2014 & 16.9 \\
\hline 2015 & 17.7 \\
\hline 2016 & 17.9 \\
\hline 2017 & 18.1 \\
\hline 2018 & 18.5 \\
\hline 2019 & 19.0 \\
\hline 2020 & 19.7 \\
\hline
\end{tabular}

Source: Own elaboration with data from the National Institute of Geography and Informatics, Applied Economics

Laboratory of the Autonomous University of Zacatecas,

Mexican Institute of Social Security and Ministry of Labor and Prevision, various years, 2020.

It is important to highpoint that the 19.7 million jobs that are had in the year 2020 were considerably reduced for the month of June of the indicated year, because of the health and economic pandemic that affects the country in a very spectacular way. It's calculated that the loss of jobs will be greater than 1.5 million in the coming months. We must point out, that it's one of the most negative ravages of the crisis that the world and Mexico are suffering. An interesting aspect to consider in this area of employment is constituted in Mexico by the so-called contingent contracts that add up to approximately 2.9 million for the year 2020 that are constantly renewed, either monthly or quarterly. Many of them disappeared due to the closure of companies, a result of the pandemic.

According to the data provided by the Ministry of Labor and Social Welfare (STPS), until March 2020, there were 2 million 589 thousand 243 formal jobs in urban areas of a temporary nature reported to the IMSS, while those in the field represented 303 thousand 699, giving a total in this sense of 2,892,942. At the same time, for the month of May 2020, the official figure provided by the federal government was 346 thousand laid off from their source of work for two fundamental reasons: definitive closure of the company or temporary closure waiting for the green light to open (when the red light passes and all the companies are definitively opened).

It's common that in urban areas, the majority of temporary jobs are in services, construction and transportation. Special attention is drawn to construction workers with projects that were halted by the health emergency, in the tourism sector that had been hired for the Easter holiday period and Summer Vacation, which was also affected, and those who are hired under outsourcing.

We can conclude that the majority of those laid off by the crisis are not in a formal regime with all benefits. Populations that have historically been the most vulnerable continue to be those most at risk from job layoffs, dramatically increasing unemployment levels in Mexico in an alarming way. At this point, it's worth remembering the contingency from 2009 called A/H1N1. In this period, formal employment in Mexico had a drop in jobs that wasn't reversed until eight months after the sanitary measures began, at the same time that informal employment grew by more than 1.6 million places. Despite this, the gross value of the production of the informal economy fell (Jiménez, 2020, p. 15).

For the month of May 2020, the International Labor Organization (ILO) warned of a possible growth of informal employment in the world with the current COVID19 pandemic, accompanied by the risk of increased poverty among those who work in this sector. Likewise, based on the records of the Ministry of Labor, the IMSS and the National Survey of Occupation and Employment (ENOE) prepared by the National Institute of Statistics and Geography (INEGI) [15], 2009 was one of the most complicated in terms of job creation. This happened largely due to the emergency caused by the outbreak of influenza $\mathrm{A} / \mathrm{H} 1 \mathrm{~N} 1$ in Mexico, which forced the closure of a large part of the labor sector, but with measures that lasted only a few weeks.

The statistics registered by the ENOE indicate that in the first quarter of 2009 , prior to the outbreak, there were 44 million 627 thousand workers in total in the country, of which 26 million 169 thousand were in the informal sector. For the last quarter of that year, total employment rose to 46.3 million, but most of these jobs were generated in the informal sector, which rose to 27 million 815 workers. In 2019, INEGI also reported that, despite the fact that most of the country's workers are in the informal sector, by exceeding $56 \%$, they generate a contribution of $22 \%$ to the gross domestic product, while $78 \%$ of the GDP comes from formal employment, which represents $43 \%$. 
The ILO continues to point out that in 2020, because of the COVID19 pandemic, there is a greater risk of expansion of the informal economy after the financial collapse and the closure of microenterprises, mainly in Latin America. Likewise, in the lowerincome countries it could increase poverty by up to 56 percentage points among informal workers. The latest information of June 12, 2020 about the loss of jobs as a result of the pandemic that is suffered in Mexico, reported the IMSS that there are one million 30 thousand formal jobs within the framework of the National Healthy Distance Program.

In addition, in May 2020, the IMSS continued to report in its monthly report, 344,526 formal jobs disappeared. It was the worst month of May since 1998 in Mexico: "As a consequence of the effects of the health emergency, in May there is a monthly decrease of 344 thousand 526 jobs, equivalent to a monthly rate of -1.7 percent" [3]. If the jobs lost in May are added to the 685 thousand 840 jobs that were cut in March and April, in total the jobs lost during the last three months already add up to one million 30 thousand 366 .

It's worth mentioning that the National Healthy Distance Program began on Monday, March 23, 2020 and ended on May 30, 2020, a period that covers precisely the months, in which the greatest loss of these jobs occurred. Although we must consider that for the health authorities, the healthy distance didn't end in May, but continues to this day, a situation that has the population in Mexico very alarmed.

In conclusion, we can argue the following. The average growth rate in employment during the last 36 years in Mexico (neoliberal model) was $1.8 \%$, while unemployment increased in the same period at a rate of $3.4 \%$, an indicator that shows the inability of the model to satisfy the labor demand of the population. It's necessary to highlight that in the unemployment variable, the neoliberal model implemented since the 1980s in Mexico has resulted in a low dynamism in GDP, unlike that achieved in the nationalist period, with the consequent reduced number of jobs each six-year period and with it, a considerable increase in the number of unemployed.

\section{CONCLUSIONS AND RESEARCH PERSPECTIVES}

Thus, four basic variables of the Mexican economic system were analyzed which, when combined in 2020 with two crises, the health and the economic one, provided important information on the situation that prevails in Mexico caused by COVID19. The Mexican case was reflected, which, when compared in some aspects with the USA on unemployment, as well as with some Latin American countries in GDP, showed that the health problem of the second semester of 2020, has had an immediate impact on Mexico, with the economic consequences indicated in four variables with their corresponding data.

Thus, according to private financial institutions, GDP in Mexico has decreased alarmingly throughout the year 2020 (the negative fall in GDP is calculated on average $-8 \%$ ). This situation occurred since 2019 due to a series of conditions resulting from the change of government when moving from a neoliberal model to another with an orientation that aims to favor the neediest population. The change of administration (2018) has caused significant decreases in GDP, highlighting among other factors the flight of Mexican capital abroad. The foregoing led us to consider that the GDP per capita for Mexico has remained on the rise in recent years, a situation that may be modified at the end of 2020 due to the consequences described throughout the work.

The work carried out showed that in first quarter of 2020, with the exception of sector I, referring to agriculture, forestry and fishing, the other sectors, industrial and services have had negative variations. The investments in these two sectors, II and III, the bulk of them in terms of productive investments, are made by private initiative. The tertiary activities continue to predominate in the conformation of the national GDP with an amount of 14'541.062 billion pesos, corresponding to $64.6 \%$ of the national total. In second place, is the industrial sector with $7^{\prime} 113,817$ thousand million pesos with $31.6 \%$. In last place is the first sector of the economy, such as agriculture, with only 838,349 million pesos, representing barely $3.7 \%$.

In 2020, Mexican GDP per capita will decrease $-7.6 \%$. It is estimated that at the end of the year 2020, this indicator will sink because of the crisis and reduce to 8,028 dollars. It's also necessary to consider that the GDP per capita of Mexico with respect to the USA, is still very disproportionate, due to different economic systems of these countries: in the USA, it's 65,112 dollars per year and in Mexico, it's only 10,118 dollars per year (at the beginning of the year 2020).

Regarding employment, Mexico followed an upward trend, according to the sources consulted, a situation that has changed alarmingly in 2020 as a very significant decrease was considered due to the pandemic caused by COVID19 that paralyzed since April 2020 substantial production activities in the country. The foregoing leads us to consider the result of the production stoppage in Mexico with the consequent very significant increase in job losses, immediately causing increasing unemployment that reached more than one million 100 lost jobs in the first half of 2020. 
All of the above indicates that the world, and particularly Mexico, had not experienced a situation similar to that caused by COVID19 that immediately affected the economic environment with disastrous results in the first half of 2020. Finally, we don't doubt that the situation of the two crises that we are experiencing, the health and the economic one, should propose an immediate modification to counteract the negative effects that we have experienced in the last six months. We hope that the work opens spaces for discussion on the behavior of the Mexican economy, encompassing more than four variables analyzed in this work: jobs, unemployment, remittances, foreign direct investment, inflation, interest rate, balance of payments, gross capital formation, number of companies, consumption, spending, etc. All of them will give an account of the result of the economic model implemented so far by the Mexican government in its T4. Let us remember that the ultimate purpose of any economic system is the search for social well-being rather than the individual well-being that so much economic and social havoc has caused in Mexico in years ago.

\section{REFERENCES}

1. Alcalá, F. (2020). ¿En qué es diferente la crisis económica del coronavirus de la gran recesión?, Murcia: IveaLab-Universidad de Murcia.

2. Niepoth, N., \& Bendesky, A. (2020). How Natural Genetic Variation Shapes Behavior. Annual Review of Genomics and Human Genetics, 21.

3. Cruz Martínez, A. (2020). Sección económica, en Periódico La Jornada, 13 de mayo de 2020, p. 19.

4. Gómez P. (2020). Desde el PIB hasta el bienestar, en Proceso, el 15 de mayo del 2020, México.
5. Jiménez, N. (2020). México, rumbo a una desigualdad más profunda, en Periódico La Jornada, 11 de mayo de 2020, p. 15.

6. Krugman, P. (2019). Perspectives on debt and deficits. Business Economics, 54(3), 157-159.

7. Krugman, P. (2020). Arguing with zombies: Economics, politics, and the fight for a better future. WW Norton \& Company.

8. Muñoz, A., \& Urrutia, A. (2020). Sección política, en Periódico La Jornada, 12 de junio del 2020, México, p. 13.

9. Robles S. (2020). Los efectos económicos en México y Zacatecas ocasionados por el COVID19, México: UAZ.

10. Tanuro, D. (2020). El imposible capitalismo verde y de iDemasiado tarde para ser pesimistas! La catástrofe ecológica y los medios para detenerla, Madrid: Ed. Era.

11. INEGI (Instituto Nacional de Estadística Geografía e Informática) (2020). Indicadores económicos varios años, México: INEGI.

12. Villanueva, D. (2020). Sección de economía, en Periódico La Jornada, 22 de mayo del 2020, p. 20, México.

13. Sánchez, G., \& Pérez, N. (2009). Empleo y crisis del patrón neoliberal en las entidades del país, en Revista El Cotidiano, No. 157, sep-oct 2009, México.

14. IMSS (Instituto Mexicano del Seguro Social). (2020). Cifras sobre empleo y desempleo, varios años, México, IMSS.

15. INEGI (Instituto Nacional de Estadística, Geografía e Informática). (2020). Banco de Información Económica // https://www.inegi.org.mx/sistemas/bie/__ (referred on $04 / 06 / 2020)$. 